\title{
Factors Related to Participation in the Japan Trauma Data Bank
}

\author{
Masao Ichikawa, Shinji Nakahara, and Susumu Wakai
}

\begin{abstract}
The Japan Trauma Data Bank (JTDB) was officially launched in 2004. However, widespread hospital participation in the JTDB would appear to be a difficult goal given the current lack of infrastructure for data management systems in Japan. We therefore considered it important to investigate factors affecting overall hospital participation. In our study, we mailed questionnaires to all Trauma \& Critical Care Centers and University Hospitals with Emergency Departments in Japan before the launch of the JTDB to give baseline data regarding each hospital, including their current data management system, and comparability of the recording items between their current system and the JTDB. Then the same institutions were re-surveyed three months later to check whether they had participated in the JTDB. Thirtynine of the 165 Trauma \& Critical Care Centers and 19 of the 59 University Hospitals with Emergency Departments responded to both baseline and follow-up surveys. We found that those hospitals already using computerized data management systems, and designated Trauma \& Critical Care Centers, were both more likely to have participated in the JTDB than their counterparts. Furthermore, the number of trauma patients recorded per medical doctor did not appear to affect participation. Factors making hospital participation more likely included the following: hospitals with large numbers of medical doctors; hospitals with a specially designated personal computer for data entry; hospitals employing personnel specifically for data entry; and those hospitals whose existing data management systems showed better comparability of recording items when compared to the JTDB. In summary, our study shows that participation in the JTDB, so far, appears to have been affected by the existing data management systems currently in use in hospitals throughout the country.
\end{abstract}

(JJAAM 2005; $16: 552-6$ )

Keywords: trauma registry, database, Japan Trauma Data Bank

Accepted for publication on June 13, $2005 \quad$ (05-031)

\section{Introduction}

In 2000, the Japanese Association for Acute Medicine and the Japanese Association for the Surgery of Trauma started to develop and operate a system aimed at centralizing trauma patients' medical records from hospitals in a standardized format ${ }^{1)}$. This system was to be called the Japan Trauma Data Bank (JTDB). The aim of the JTDB was to improve the quality of trauma care by compiling and analyzing data regarding the process and outcomes of the trauma care ${ }^{2)}$. The associations made announcements

Correspondence to: Masao Ichikawa, PhD

Department of Community Health, School of International Health Graduate School of Medicine, University of Tokyo

7-3-1 Hongo, Bunkyo-ku, Tokyo 113-0033, Japan in their journals, calling for the participation all hospitals involved in trauma care. Moreover, individual invitation letters were sent to Trauma \& Critical Care Centers as well as to hospitals to which board members of the associations were affiliated (personal communication, Dr. Hideo Tohira, March 7, 2005). However, noteworthy is the fact that participation was not a legislative requirement but was offered on a voluntary basis only. The JTDB was officially launched in January $2004^{11}$.

Participation of all targeted hospitals is clearly essential for a comprehensive multi-hospital data collection system $^{3)}$. However, when planning the centralization of trauma registries it seems that the current capabilities of individual hospitals to collect trauma data has been overlooked. In particular, a hospital's level of staffing and current trauma management system does not seem to have been taken into account ${ }^{4)}$. We think it fair to say that the 
ability of a hospital to participate in the JTDB, would, in fact, depend on its capacity to allocate additional time, funds and personnel in order to collate information for the new system. Moreover, this ability, in large part, would be related to the hospital's current data management system.

Japanese hospitals are usually staffed with medical record clerks but these clerks are not necessarily trained to be trauma registrars with the specific job of extracting and entering data. It is often medical doctors that are responsible for these duties. Moreover, some hospitals might not manage their medical records in a computerized system, necessitating the new acquisition of both hardware and human resources for participation in the JTDB. These factors, directly related to a hospital's infrastructure, would presumably affect its ability to participate in the JTDB.

Before the JTDB was implemented we made enquiries as to the nature of data management systems of trauma patients' medical records currently in place at Trauma \& Critical Care Centers and University Hospitals with Emergency Departments in Japan ${ }^{5)}$. We then surveyed those same hospitals to see if they had participated in the JTDB after its launch. In this study, we examined factors related to hospital participation in the JTDB.

\section{Methods}

There were 165 Trauma \& Critical Care Centers in Japan at the time of the survey; of which, 40 were affiliated with universities. The other 59 University Hospitals had Emergency Departments. We invited these 244 hospitals to the study by mailing the questionnaires in July $2003^{5)}$. By the end of December 2003, 84 hospitals replied. Three months after the start of the JTDB, we mailed the questionnaires to the 84 hospitals to check whether they had participated in it. We received the replies from 58 hospitals, with 15 having participated in the JTDB. Overall response rate was 26\%: 39 of the 165 Trauma \& Critical Care Centers (24\%) and 19 of the 59 University Hospitals with Emergency Departments (32\%) responded to both baseline and follow-up surveys; 8 of the 39 Trauma \& Critical Care Centers responding to both surveys were affiliated with universities.

In the questionnaires, we made enquiries regarding basic hospital statistics (number of medical doctors of the center/department, number of trauma patients recorded in the last 12 months), current data management systems (whether they were computerized, whether hospitals had designated personnel for data entry and whether Emer- gency Departments had a designated personal computer for data entry), and comparability of the recording items between current systems and the JTDB (whether the information required for entry into the JTDB already existed in their current data management system) ${ }^{5}$. In our numbers we only included medical doctors who worked for a center/department for at least three days a week for the reason that there are some medical doctors who only work for a center/department on an occasional basis. To estimate the burden of the data entry, we calculated the number of trauma patients recorded per medical doctor. An outcome variable was their participation in the JTDB.

We compared the proportion of hospitals participating in the JTDB by type of hospital (center/department) and by data pertaining to each hospital and its current data management system, to determine factors related to participation in the JTDB. For these comparisons, we calculated odds ratios and their 95\% confidence intervals. Furthermore, we made a comparison between Trauma \& Critical Care Centers and Emergency Departments with regard to their general profiles and their data management systems.

\section{Results}

Those hospitals already using computerized data management systems and designated Trauma \& Critical Care Centers were more likely to have participated in the JTDB than their counterparts. The number of trauma patients recorded in the last 12 months and the number of trauma patients recorded per medical doctor did not seem to affect participation. The hospitals with a larger number of medical doctors had a greater tendency to participate in the JTDB; so too did hospitals with a specially designated personal computer for data entry and those employing personnel specifically for the purpose of data entry, as well as those hospitals whose data management systems' recoding items were more comparable to those of the JTDB (Table 1).

Trauma \& Critical Care Centers tended to have a computerized system, more comparable data contents, personnel for data entry, and a larger number of medical doctors and trauma patients recorded per medical doctor, compared to the Emergency Departments (Table 2).

\section{Discussion}

The more familiar with a computerized data-management system, the less hesitant hospitals are at participa- 
Table 1. Number and proportion of hospitals participating in the Japan Trauma Databank (JTDB), listed by the characteristics of the hospitals and their data management system; odds ratio (OR) and its 95\% confidence interval (CI) for participation in the JTDB.

\begin{tabular}{|c|c|c|c|c|}
\hline & \multirow{2}{*}{$\begin{array}{l}\text { No. of } \\
\text { response }\end{array}$} & \multicolumn{2}{|c|}{ Participating hospitals } & \multirow{2}{*}{ OR $(95 \% \mathrm{CI})$} \\
\hline & & $\mathrm{n}$ & $\%$ & \\
\hline \multicolumn{5}{|l|}{ Type of hospital } \\
\hline Trauma \& Critical Care Center & 39 & 14 & 36 & $10.10(1.21$ to 83.33$)$ \\
\hline Emergency Department & 19 & 1 & 5 & \\
\hline \multicolumn{5}{|l|}{ No. of medical doctors* } \\
\hline $10+$ & 15 & 7 & 47 & $3.17(0.88$ to 11.42$)$ \\
\hline$<10$ & 37 & 8 & 22 & \\
\hline \multicolumn{5}{|c|}{ No. of trauma patients recorded in the last 12 months } \\
\hline$<300$ & 25 & 7 & 28 & $0.97(0.29$ to 3.22$)$ \\
\hline $300+$ & 28 & 8 & 29 & \\
\hline \multicolumn{5}{|c|}{ No. of trauma patients recorded per medical doctor } \\
\hline$<100$ & 29 & 9 & 31 & $0.90(0.26$ to 3.16$)$ \\
\hline $100+$ & 18 & 6 & 33 & \\
\hline \multicolumn{5}{|l|}{ Data management system } \\
\hline Computerized & 31 & 13 & 42 & $9.01(1.81$ to 45.45$)$ \\
\hline Not computerized & 27 & 2 & 7 & \\
\hline \multicolumn{5}{|c|}{ Specifically designated personal computer for data entry $\dagger$} \\
\hline Available & 26 & 12 & 46 & $3.43(0.34$ to 34.99$)$ \\
\hline Not available & 5 & 1 & 20 & \\
\hline \multicolumn{5}{|l|}{ Personnel for data entry } \\
\hline Available & 15 & 5 & 33 & $1.65(0.46$ to 5.97$)$ \\
\hline Not available & 43 & 10 & 23 & \\
\hline \multicolumn{5}{|c|}{ Proportion of the JTDB items already in existence in the current system } \\
\hline $50 \%+$ & 23 & 7 & 30 & $1.31(0.40$ to 4.34$)$ \\
\hline$<50 \%$ & 32 & 8 & 25 & \\
\hline
\end{tabular}

* Those working for the center/department for at least 3 days a week

$\dagger$ Only among hospitals with computerized data management systems

Table 2. Comparison of 39 Trauma \& Critical Care Centers (TC) and 19 Emergency Departments (ED).

\begin{tabular}{|c|c|c|c|c|}
\hline & \multicolumn{2}{|c|}{ TC } & \multicolumn{2}{|c|}{ ED } \\
\hline & $\mathrm{n}$ & $\%$ & $\mathrm{n}$ & $\%$ \\
\hline No. of medical doctors* $(10+)$ & 12 & 34.3 & 3 & 17.6 \\
\hline No. of trauma patients recorded in the last 12 months $(300+)$ & 23 & 59.0 & 5 & 35.7 \\
\hline No. of trauma patients recorded per medical doctor $(100+)$ & 14 & 41.2 & 4 & 30.8 \\
\hline Data management system (computerized) & 25 & 64.1 & 6 & 31.6 \\
\hline Specifically designated personal computer for data entry (available) $\dagger$ & 21 & 84.0 & 5 & 83.3 \\
\hline Personnel for data entry (available) & 12 & 30.8 & 3 & 15.8 \\
\hline Proportion of the JTDB items already in existence in the current system $(50 \%+)$ & 19 & 48.7 & 4 & 25.0 \\
\hline
\end{tabular}

* Those working for the center/department for at least 3 days a week

$\dagger$ Only among hospitals with computerized data management systems 
tion in the JTDB. This finding seems reasonable and could be an explanation for the lower participation rate of Emergency Departments where computerized systems were not already in use. Of the proxy variables for the burden of extracting and entering data, "the number of trauma patients recorded per medical doctor," and "comparability of the recording items between the current system and the JTDB" seem to have the least influence on hospital participation, while "availability of personnel for data entry" seems to have had most impact on encouraging hospital participation. In order to promote hospital participation and improve the quality of the JTDB data it would seem that the recruitment of data-entry workers would be the most effective intervention a hospital could employ. This intervention not only reduces the burden of data collection for medical doctors but, very importantly, also improves the accuracy of the data entered ${ }^{6}$.

The limitations of this study should be acknowledged. Firstly, we were unable to examine the relative importance of the factors influencing participation because of the low number of the hospitals who actually replied to our questionnaire and because the amount of complete data was too small to do multivariate analyses. Secondly, only one-fourth of the hospitals we contacted replied. Generalizability of our findings might be restricted because the Trauma \& Critical Care Centers were under-represented in the survey. It might be the case that hospitals not answering the questionnaire do not have a great interest in the JTDB, and thus would not participate in the JTDB even if, for example, their current data management system was computerized. A key element in encouraging participation in the JTDB is through making its true benefit known to target institutions from the outset ${ }^{1)}$.

In conclusion, participation in the JTDB appears to have been affected by the existing data management systems currently in use in hospitals. A possible way to increase participation in the future, is to train and allocate trauma registrars and to make technical assistance available within all target hospitals, especially those just starting to computerize their data management systems. All these inter- ventions will necessitate ongoing funding ${ }^{7,8)}$.

\section{Acknowledgments}

We thank all the respondents of this study, the Committee of Clinical Indicators for Quality Assurance of the Japanese Association for Acute Medicine (Chair: Tetsuya Sakamoto) and the Committee on Trauma Registry of the Japanese Association for the Surgery of Trauma (Chair: Kazuhide Ozeki) for their kind cooperation. This work was supported by the Ministry of Education, Culture, Sports, Science and Technology Grant-in-Aid for Young Scientists B (15790296).

\section{References}

1) Ozeki K, Mashiko K, Sakamoto T, et al: Activities and perspectives of the Trauma Registry Committee. J Jpn Assoc Surg Trauma 2004; 18: 394-9 [Japanese].

2) Japanese Association for Acute Medicine, Japanese Association for the Surgery of Trauma. Japan Trauma Databank regulations. Available at: http://www.tororo.net/traumabank/ dataroom/data/jtdb_kisoku_1115.pdf Accessed March 24, 2004.

3) Brenner RA, Scheidt PC, Rossi MW, et al: Injury surveillance in the ED: design, implementation, and analysis. Am J Emerg Med 2002; 20: 181-7.

4) Pollock DA, McClain PW: Trauma registries. Current status and future prospects. JAMA 1989; 262: 2280-3.

5) Ichikawa $M$, Nakahara $S$, Wakai $S$ : Trauma registries in Japan. J Jpn Ass Acute Med 2005; 16: 149-56 [Japanese].

6) Saito T, Ozeki K, Mashiko K, et al: Anticipation and problems involved in medical research using trauma registry. $\mathrm{J}$ Jpn Assoc Surg Trauma 2004; 18: 423-5 [Japanese].

7) Mackenzie SG, Pless IB: CHIRPP: Canada's principal injury surveillance program. Canadian Hospitals Injury Reporting and Prevention Program. Inj Prev 1999; 5: 208-13.

8) Lyons RA, Jones S, Kemp A, et al: Development and use of a population based injury surveillance system: the All Wales Injury Surveillance System (AWISS). Inj Prev 2002; 8: 836. 


\section{原著論文}

\section{日本外傷データバンク（JTDB）参加に関連する要因の検討}

市川 政雄 中原 慎二 若井晋

要旨 日本外傷データバンク（JTDB）が 2004 年に開始されたが，その対象施設が JTDBに参加できるか否かは 各施設の診療記録の管理体制に左右されると考えられる。そこで，具体的にどのような要因がJTDBへの参加あ るいは不参加に関係しているか検討した。まずJTDB開始前に, 救命救急センターと大学病院救急部における外 傷登録の現状 (登録内容, 登録患者数, データベース化の有無, 入力用コンピュータの有無, 入力スタッフの有 無など）を把握するため，自記式調査票を用いたベースライン調査を実施した。そしてJTDB 開始 3 か月後に， ベースライン調査に応じた施設がJTDBに参加しているかどうか確認するため，フォローアップ調査を実施した。 ベースライン調査とフォローアップ調査の両方に応じた施設は, 救命救急センター165施設のうち39施設, 大学 病院救急部 59 施設のうち 19 施設であった。外傷登録の現状を分類して JTDBへの参加施設の割合を比較した結 果, 診療記録をデータベース化している施設ならびに救命救急センターにおいて参加施設の割合が高かった。医 師一人あたりの登録患者数が多くても少なくても, 参加施設の割合に大きな違いは見られなかった。医師数が多 い施設, データ入力用のコンピュータや入力スタッフを有する施設，JTDBの入力項目が既存の診療記録に多く 含まれている施設においては, 参加施設の割合が高い傾向にあった。以上のことから, JTDBへの参加の可否は 既存の診療記録の管理体制に依存しているといえる。

(日救急医会誌 $2005 ; 16: 552-6$ )

キーワード：外傷登録, データベース, 日本外傷データバンク

著者連絡先： $\bar{\top} 113-0033$ 東京都文京区本郷 7-3-1 東京大学大学院医学系研究科国際地域保健学教室 原稿受理日：2005 年 6 月 13 日（05-031） 